\title{
Meretas Kebekuan Ijtihad Menghadap Arah Qiblat
}

\author{
Dhiauddin Tanjung \\ UIN Sumatera Utara dhiauddintj@yahoo.com
}

\begin{abstract}
Abstrak
Qibla ( , also transliterated as Qiblah, Kibla or Kiblah) is an Arabic word for the direction that should be faced when a Muslim prays during Salat. Most mosques contain a niche in a wall that indicates the qibla. The qibla has importance to more than just the Salat, and plays an important part in everyday ceremonies.

\section{Kata-Kata Kunci : Qibla, jihah, syathrah, 'Ainul Ka'bah, Mekah}

\section{Pendahuluan}

Dalam melaksanakan ibadah shalat seseorang harus menghadap ke arah qiblat, menghadap ke arah qiblat ketika shalat merupakan syarat sah shalat, artinya tanpa menghadap ke arah qiblat maka shalat yang dilakukan tidak sah.

Persoalan menghadap qiblat saat melaksanakan shalat ini, menjadi kajian dan persoalan yang menarik untuk dikaji dan diteliti, oleh karena setiap muslim yang hendak melaksanakan shalat selalu berasumsi dan menyangka bahwa yang dilakukannya adalah menghadap qiblat, selalu berniat bahwa sedang menghadap qiblat, atau berniat menghadap ke arah qiblat, atau berniat menghadap syathrah al-qiblah, padahal kalau di teliti (dilakukan penelitian) belum tentu arah yang dimaksud adalah qiblat (Ka'bah), mungkin saja sudah mengalami deviasi/penyimpangan arah sehingga menjadi ke arah lain.

\section{Pengertian Arah Qiblat}

Arah dalam bahasa Indonesia dijelaskan ; kata "arah" itu

mempunyai dua arti, yaitu "menuju" dan "menghadap ke". 1

Arah dalam bahasa Arab disebut jihah atau syathrah dan kadang-kadang disebut juga dengan qiblah (dalam bentuk mashdar) yang berasal dari kata qabbala yaqbulu qiblah yang artinya menghadap. ${ }^{2}$

Kata qiblat berasar dari bahasa Arab asal katanya ialah , sinonimnya adalah وجهة yang berasal dari kata موجهة artinya adalah keadaan arah yang dihadapi, kemudian pengertiannya dikhususkan pada suatu arah, dimana semua orang yang mendirikan shalat menghadap kepadanya. ${ }^{3}$

${ }^{1}$ Departemen P \& K, Kamus Besar Bahasa Indonesia (Jakarta : Balai Pustaka, 1989), cet. 2., h. 46.

2 Ahmad Warson Munawwir, Kamus al-Munawwir Arab Indonesia Terlengkap (Yogyakarta : Pustaka Progresif, 1984 ), cet. I., h. 1169. Lihat juga : Louwis Ma'luf, Al-Munjid (Mesir: Dar al-Masyriq, 1975), Cet ke-25, h. 606-607. Lihat: Musthofa al-Ghalayaini, Jami'ud Durusul 'Arabiyyah (Beirut: Mansyuratul Maktabul 'Ishriyyah, t.th.), h. 161.

3 Ahmad Mustafa Al-Maraghi, Terjemah Tafsir Al-Maraghi, penerjemah : Anshori Umar Sitanggal (Semarang: CV. Toha Putra, 1993), Juz II, h. 2.
\end{abstract}


Adapun qiblat atau kiblat diartikan dengan arah ke Ka'bah di Mekah (pada waktu shalat) ${ }^{1}$, sedangkan dalam bahasa latin disebut Azimuth, ${ }^{2}$ Abdul Aziz Dahlan dan kawan-kawan, sebagaimana dikutif juga oleh Ahmad Izzuddin mendefenisikan qiblat sebagai bangunan Ka'bah atau arah yang dituju kaum muslimin dalam melaksanakan sebagian ibadah. ${ }^{3}$

Sedangkan Harun Nasution, mengartikan qiblat sebagai arah untuk menghadap pada waktu shalat. ${ }^{4}$ Sementara Mochtar Effendy mengartikan qiblat sebagai arah shalat, arah Ka'bah di kota Mekah. Departemen Agama Republik Indonesia mendefenisikan qiblat sebagai suatu arah tertentu bagi kaum muslimin untuk mengarahkan wajahnya dalam melakukan shalat. ${ }^{6}$

${ }^{1}$ Departemen Pendidikan

Nasional, Kamus Besar Bahasa Indonesia (Jakarta: Balai Pustaka, 2007), Edisi Ketiga, h. 566. Lihat juga : Departemen P \& K,

Kamus Besar Bahasa Indonesia...., h. 438.

${ }^{2}$ Depag, Pedoman Penentuan

Arah Kiblat (Jakarta: Dirjen Binbaga Islam Dirbinpera, 1996 ), h. 10.

${ }^{3}$ Abdul Aziz Dahlan, et al., Ensiklopedi Hukum Islam (Jakarta: PT. Ichtiar Baru Van Hoeve, 1996), Cet. Ke-1, h. 944. Lihat juga : Ahmad Izzuddin, Ilmu Falak Praktis: Metode Hisab-Rukyat Praktis dan Solusi Permasalahannya (Semarang: PT. Pustaka Rizki Putra, 2012), h. 19-20.

${ }^{4}$ Harun Nasution, et.al.,

Ensiklopedi Hukum Islam (Jakarta:

Djambatan, 1992), h. 563.

${ }^{5}$ Mochtar Effendy, Ensiklopedi

Agama dan Filsafat (Palembang:

Universitas Sriwijaya, 2001), Cet. Ke-1,

Vol. 5, h. 49.

${ }^{6}$ Departemen Agama RI.,

Direktorat Jenderal Pembinaan

Kelembagaan Agama Islam Proyek

Peningkatan Prasarana dan Sarana

Perguruan Tinggi Agama/IAIN, Ensiklopedi
Slamet Hambali memberikan defenisi arah qiblat yaitu arah menuju Ka'bah (Baitullah) melalui jalur paling terdekat, dan menjadi keharusan bagi setiap orang muslim untuk menghadap ke arah tersebut pada saat melaksanakan ibadah shalat, di manapun berada di belahan dunia ini. ${ }^{7}$ Sedangkan Muhyiddin Khazin memberi defenisi dengan arah atau jarak terdekat sepanjang lingkaran besar yang melewati ke Ka'bah (Mekah) dengan tempat kota yang bersangkutan. ${ }^{8}$

Sedangkan Nurmal Nur mengartikan qiblat sebagai arah yang menuju ke Ka'bah di Masjidil Haram Mekah, dalam hal ini seorang muslim wajib menghadapkan mukanya tatkala ia mendirikan shalat atau dibaringkan jenazahnya di liang lahat. ${ }^{9}$

Dengan demikian dari segi bahasa Arah Qiblat berarti menghadap ke Ka'bah ketika shalat. Sementara itu Arah sendiri adalah jarak terdekat dari suatu tempat ke Mekah. ${ }^{10} \quad$ Sederhananya yang

Islam (Jakarta: CV. Anda Utama, 1993), h. 629.

7 Slamet Hambali, Ilmu Falak I : Penentuan Awal Waktu Shalat dan Arah Kiblat Seluruh Dunia (Semarang: Program Pascasarjana IAIN Walisongo Semarang, 2011), h. 167.

${ }^{8}$ Muhyiddin Khazin, Ilmu Falak

Dalam Teori dan Praktik (Yogyakarta: Buana Pustaka, 2004), h. 48.

9 Nurmal Nur, Ilmu Falak

(Teknologi Hisab Rukyat Untuk Menentukan Arah Kiblat, Awal Waktu Shalat dan Awal Bulan Qamariah (Padang: IAIN Imam Bonjol Padang, 1997), h. 23.

10 Jan van den Brink dan Marja Meeder, Kiblat Arah Tepat Menuju Mekah, disadur oleh Andi Hakim Nasution dari "Mecca", (Jakarta : Litera Antar Nusa, 1993 ), cet. 1. h. 2 . 
dimaksud dengan Arah Qiblat dalam penelitian ini adalah menghadap ke arah qiblat dengan jarak yang terdekat ke Ka'bah di Mekah, dan setiap muslim wajib menghadap ke arahnya saat mengerjakan shalat.

\section{Dalil-Dalil Perintah Menghadap Arah Qiblat}

Ada beberapa Nash yang memerintahkan kita untuk menghadap qiblat dalam shalat baik Al-Qur'an maupun Hadis.

1. Al-Qur'an

Ayat-Ayat al-Qur'an yang berhubungan dengan pembahasan qiblat adalah ;

a. QS. Al-Baqarah/2; 115 :

وَلِلَّهِ آلمَشُرِقُ وَآلََغْرِبُ

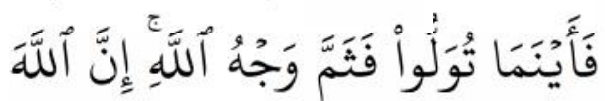

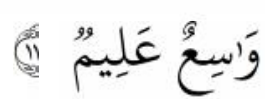

Artinya: Dan kepunyaan Allahlah timur dan barat, maka kemanapun kamu menghadap di situlah wajah Allah. Sesungguhnya Allah Maha Luas (Rahmat-Nya) lagi Maha Mengetahui. (QS. AlBaqarah/2; 115) ${ }^{1}$

b. QS. Al-Baqarah/2; 142 :
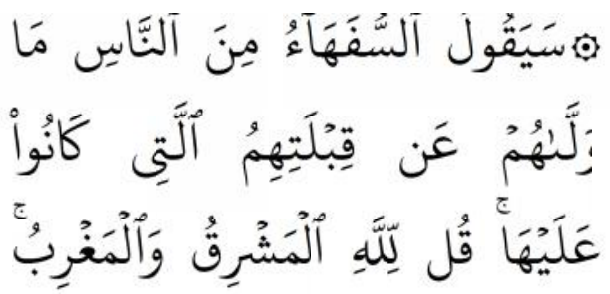

1 Departemen Agama RI, AlQur'an dan Terjemahnya..., h. 31.

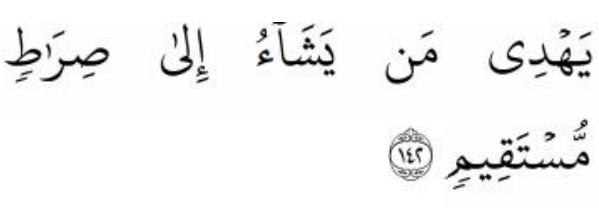

Artinya : Orang-orang yang kurang akalnya, diantara manusia akan berkata: "Apakah yang memalingkan mereka (umat Islam) dari kiblatnya (Baitul Maqdis) yang dahulu mereka telah berkiblat kepadanya?" Katakanlah:

"Kepunyaan Allah-lah timur dan barat; Dia memberi petunjuk kepada siapa yang dikehendaki-Nya ke jalan yang lurus". (QS. Al-Baqarah/2; 142) ${ }^{2}$

c. QS. Al-Baqarah/2; 143 :

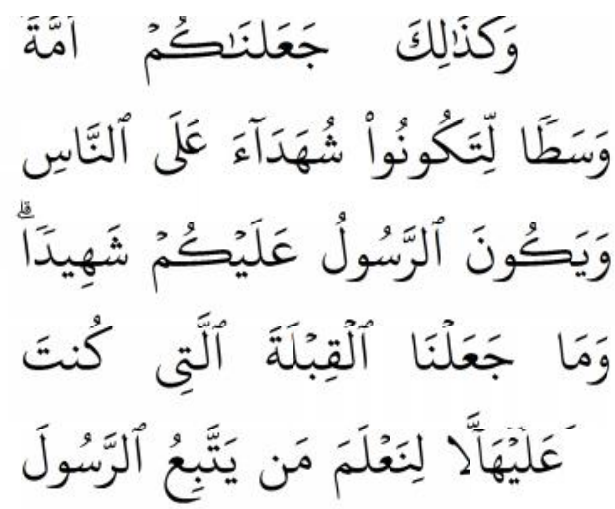

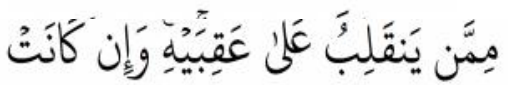

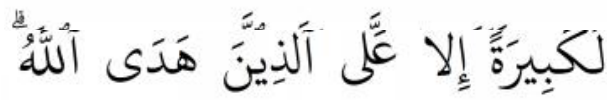

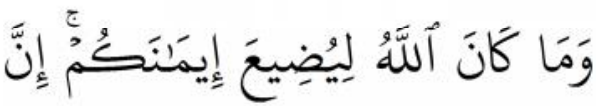

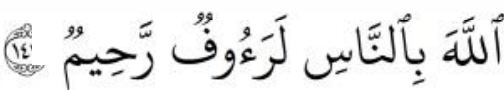

Artinya : Dan demikian (pula) Kami telah menjadikan kamu (umat Islam), umat yang adil dan pilihan, agar kamu menjadi saksi atas

${ }^{2}$ Ibid, h. 32. 
(perbuatan) manusia dan agar Rasul (Muhammad) menjadi saksi atas (perbuatan) kamu. dan Kami tidak menetapkan qiblat yang menjadi qiblatmu (sekarang) melainkan agar Kami mengetahui (supaya nyata) siapa yang mengikuti Rasul dan siapa yang membelot. dan sungguh (pemindahan qiblat) itu terasa amat berat, kecuali bagi orang-orang yang telah diberi petunjuk oleh Allah; dan Allah tidak akan menyianyiakan imanmu. Sesungguhnya Allah Maha Pengasih lagi Maha Penyayang kepada manusia. (QS. Al-Baqarah/2; 143) ${ }^{1}$

d. QS. Al-Baqarah/2; 144 :
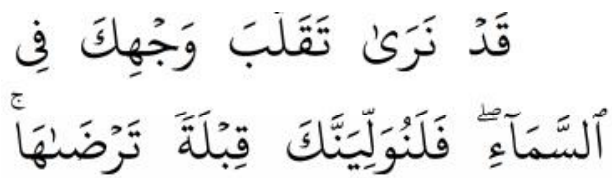

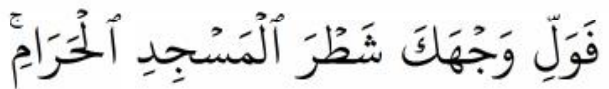

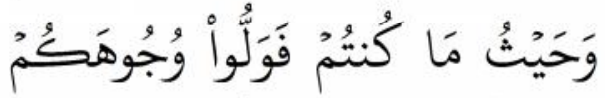

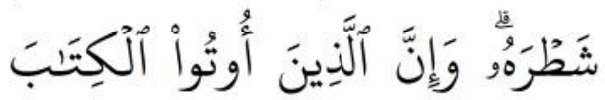

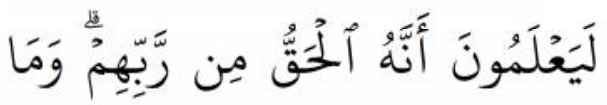
أَلَّهُ بِغَفِلِ عَنَّا يَعْمَلُونَ

Artinya : Sungguh kami (sering) melihat mukamu menengadah ke langit, ${ }^{2}$, maka sungguh kami akan memalingkan kamu ke qiblat yang kamu sukai. palingkanlah mukamu ke arah

${ }_{2}^{1}$ Ibid, h. 32. Muhammad SAW. sering melihat ke langit mendoa dan menunggu-nunggu Turunnya wahyu yang memerintahkan beliau menghadap ke Baitullah.
Masjidil Haram. dan dimana saja kamu berada, palingkanlah mukamu ke arahnya. dan sesungguhnya orang-orang (Yahudi dan Nasrani) yang diberi Al-Kitab (Taurat dan Injil) memang mengetahui, bahwa berpaling ke Masjidil Haram itu adalah benar dari Tuhannya; dan Allah sekali-kali tidak lengah dari apa yang mereka kerjakan. (QS.AlBaqarah $/ 2 ; 144){ }^{3}$

e. QS. Al-Baqarah/2; 149 dan 150.

وَمِنْ حَيْثُ خَرَجْتَ فَوَلِ

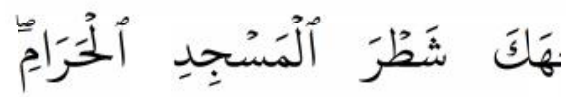

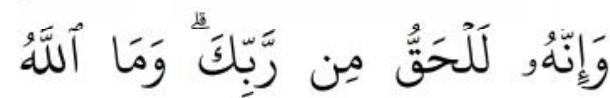

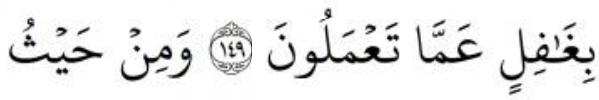

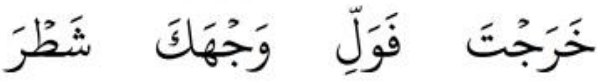

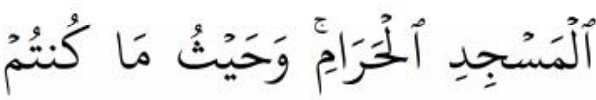
فَوَلُّواً وُجُوهَهُمُ شَطُرَهُو لِعَلَّلا

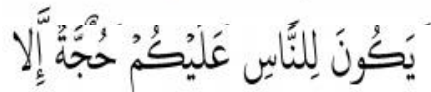

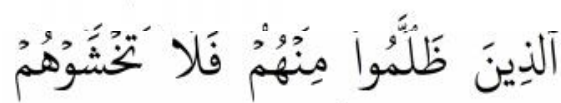

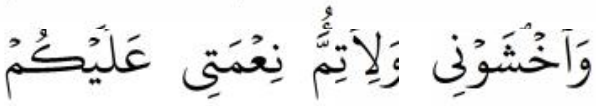

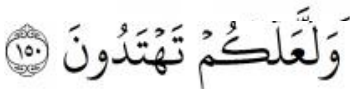

Artinya : Dan daxi „manai sia kamu keluar (datang), maka palingkanlah wajahmu ke arah Masjidil Haram, sesungguhnya

3 Departemen Agama RI., Alquran dan Terjemahnya..., h. 22. 
ketentuan itu benar-benar sesuatu yang hak dari Tuhanmu. dan Allah sekali-kali tidak lengah dari apa yang kamu kerjakan.(149). Dan dari mana saja kamu (keluar), maka palingkanlah wajahmu ke arah Masjidil Haram. dan dimana saja kamu (sekalian) berada, maka palingkanlah wajahmu ke arahnya, agar tidak ada hujjah bagi manusia atas kamu, kecuali orang-orang yang zalim di antara mereka. Maka janganlah kamu takut kepada mereka dan takutlah kepada-Ku (saja). dan agar Ku-sempurnakan nikmat-Ku atasmu, dan supaya kamu mendapat petunjuk.(150). (QS. AlBaqarah/2; 149-150). ${ }^{1}$

\section{f. QS. Al-Baqarah/2; 177}

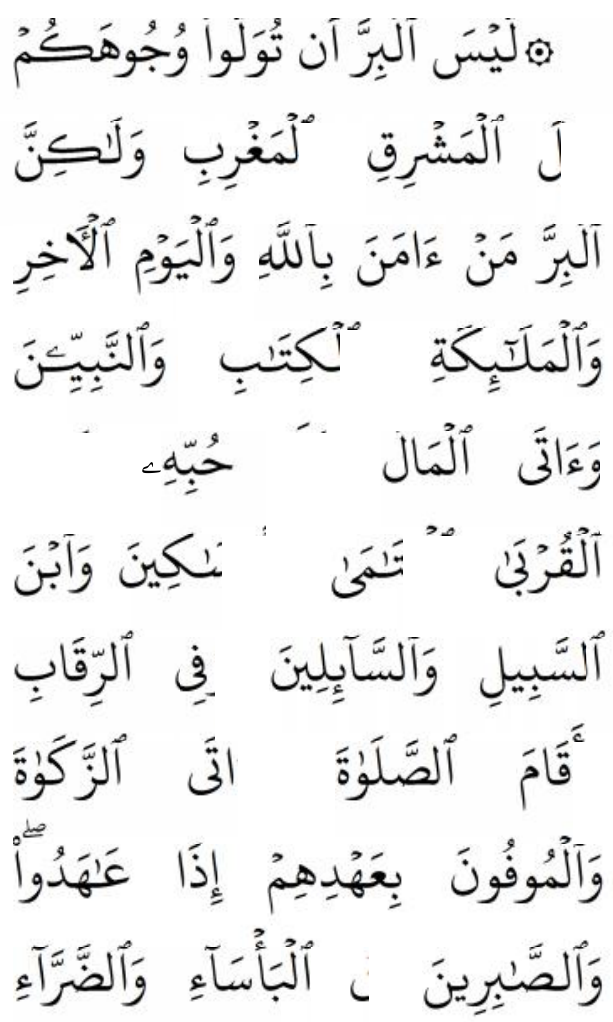

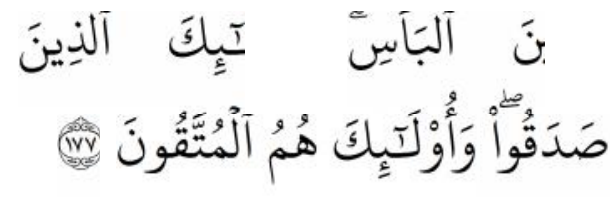

ArtinyaBukanlah: menghadapkan wajahmu ke arah timur dan barat itu suatu kebajikan, akan tetapi sesungguhnya kebajikan itu ialah beriman kepada Allah, hari Kemudian, malaikat-malaikat, kitabkitab, nabi-nabi dan memberikan harta yang dicintainya kepada kerabatnya, anak-anak yatim, orangorang miskin, musafir (yang memerlukan pertolongan) dan orang-orang yang meminta-minta; dan (memerdekakan) hamba sahaya, mendirikan shalat, dan menunaikan zakat; dan orang-orang yang menepati janjinya apabila ia berjanji, dan orang-orang yang sabar dalam kesempitan, penderitaan dan dalam peperangan. mereka itulah orang-orang yang benar (imannya); dan mereka i.tulah orang-orang yang bertakwa. (QS. Al-Baqarah/2; 177). ${ }^{2}$

\section{Al-Hadis}

Di antara Hadis-Hadis yang berhubungan dengan pembahasan qiblat adalah ;

a. HR. Bukhari :

مَّمَ

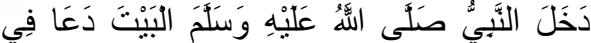

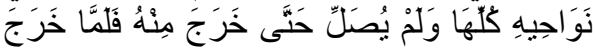

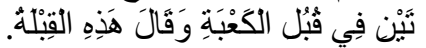

Artinya : ... dari 'Atha' berkata, aku mendengar Ibnu 'Abbas berkata, ketika Nabi Saw. masuk ke dalam Ka'bah, beliau berdo'a di seluruh sisinya dan tidak melakukan

\footnotetext{
${ }^{1}$ Ibid,. h. 23.
}

${ }^{2}$ Ibid,. h. 43. 
shalat hingga beliau keluar darinya. Beliau kemudian shalat dua rakaat dengan memandang Ka'bah lalu bersabda: Inilah qiblat. (HR. Bukhari).

b. HR. Bukhari :

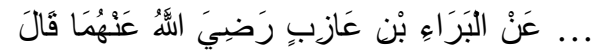

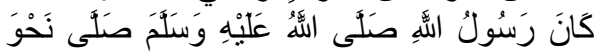

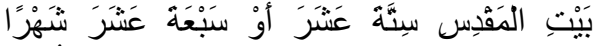

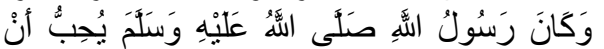

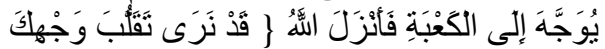

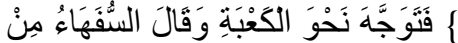

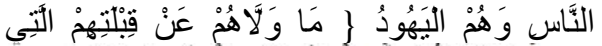

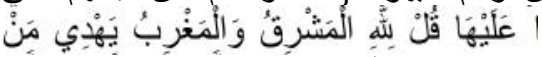

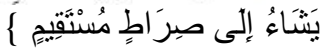
السَُّ عَلْنْهِ

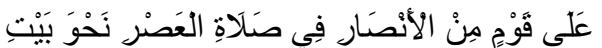

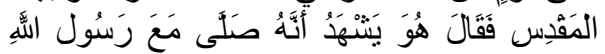

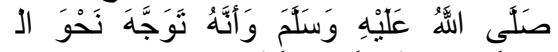

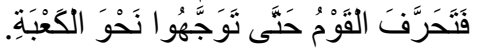

Artinya : ... dari Al Bara' bin 'Azib Radliallahu 'anhuma berkata, Rasulullah Saw. shalat menghadap Baitul Maqdis selama enam belas atau tujuh belas bulan, dan Rasulullah Saw. menginginkan qiblat tersebut dialihkan ke arah Ka'bah. Maka Allah menurunkan ayat: (Sungguh Kami (sering) melihat mukamu menengadah ke langit) (QS. Al-Baqarah: 144). Maka kemudian Nabi Saw. menghadap ke Ka'bah. Lalu berkatalah orang-orang yang kurang akal, yaitu orang-orang Yahudi: (Apakah yang memalingkan mereka (umat Islam) dari qiblatnya (Baitul Maqdis) yang dahulu mereka telah berkiblat kepadanya? Katakanlah: Kepunyaan Allah-lah timur dan barat. Dia memberi petunjuk kepada siapa yang dikehendaki-Nya ke jalan yang lurus) (QS. Al-Baqarah: 144). Kemudian ada seseorang yang ikut shalat bersama Nabi Saw., orang itu kemudian keluar setelah menyelesikan shalatnya. Kemudian orang itu melewati Kaum Anshar yang sedang melaksanakan shalat 'Ashar dengan menghadap Baitul Maqdis. Lalu orang itu bersaksi bahwa dia telah shalat bersama Rasulullah Saw. dengan menghadap Ka'bah. Maka orang-orang itu pun berputar dan menghadap Ka'bah. (HR. Bukhari).

c. HR. Bukhari :

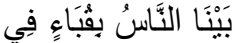

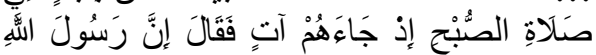

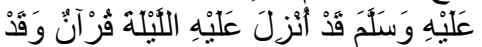

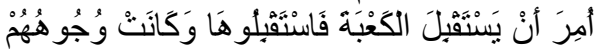

Artinya : ... dari 'Abdullah bin 'Umar berkata, ketika orang-orang shalat subuh di Quba', tiba-tiba datang seorang laki-laki dan berkata, sungguh, tadi malam telah turun ayat kepada Rasulullah Saw., beliau diperintahkan untuk menghadap ke arah Ka'bah. Maka orang-orang yang sedang shalat berputar menghadap Ka'bah, padahal pada saat itu wajah-wajah mereka sedang menghadap negeri Syam. Mereka kemudian berputar ke arah Ka'bah. (HR. Bukhari).

d. HR. Bukhari :

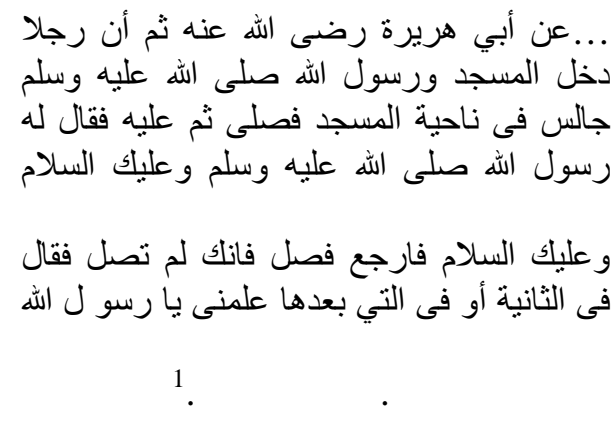

1 Abu Na'im Ahmad bin Ishaq AlAshbahani, Al-Musnad Al-Mustakhraj 'Ala 
Artinya : ... dari Abu Hurairah ra. bahwasanya seorang laki-laki masuk masjid, saat itu Rasulullah Saw. duduk di salah satu sudut sisi Masjid, lalu laki-laki itu shalat, setelah shalat, Rasulullah Saw. memanggilnya dan berkata ; atasmu keselamatan, ulangilah kembali shalatmu, sesungguhnya engkau belum melaksanakan shalat, laki-laki itu kembali mengulangi shalatnya, akan tetapi Rasul kembali berkata; atasmu keselamatan, ulangilah kembali shalatmu, sesungguhnya engkau belum melaksanakan shalat, kemudian laki-laki itu berkata; ajari aku wahai Rasulullah, lalu Rasulullah Saw. bersabda : apabila engkau melaksanakan shalat maka sempurnakanlah wudhu'mu, lalu menghadaplah qiblat dan bertakbirlah. (HR. Bukhari).

e. HR. Bukhari :

$$
\begin{aligned}
& \text { قال أبو هريرة رضي الله عنه قال : }
\end{aligned}
$$

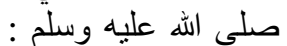

Artinya : Dari Abu Hurairah ra. berkata : Rasulullah Saw. bersabda: menghadaplah qiblat lalu bertakbirlah (HR. Bukhari).

f.HR. Muslim :

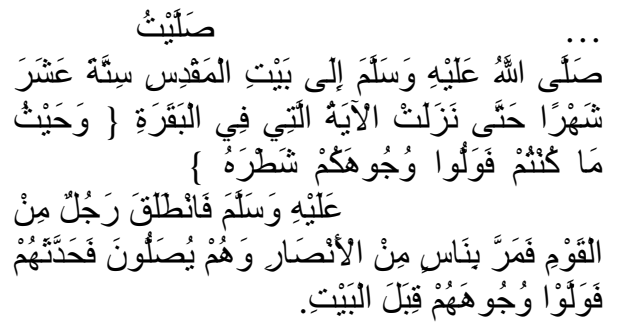

Shahih Imam Muslim (Beirut : Dar al-Kutub, 1996), Jilid 2, h. 130.
Artinya : ... dari al-Bara' bin 'Azib dia berkata, aku shalat bersama Nabi Saw. menghadap Baitul Maqdis selama enam belas bulan hingga turun ayat tersebut yang ada dalam surat Al-Baqarah, dan di mana pun kamu berada maka palingkanlah wajah-wajahmu ke arahnya. (QS.Al-Baqarah 144), ayat tersebut turun setelah Nabi Saw. shalat, lalu seorang laki-laki dari suatu kaum bertolak pergi, lalu dia berjalan bersama beberapa manusia dari kalangan Anshar, dan mereka shalat, lalu beliau menceritakannya kepada mereka, maka mereka menghadapkan wajah-wajah mereka ke Baitullah. (HR. Muslim).

g. HR. Muslim :

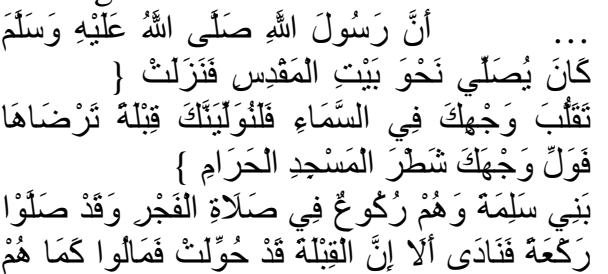

Artinya : ... dari Anas bahwa Rasulullah Saw. dahulu shalat menghadap Baitul Maqdis, lalu turunlah ayat ; Sungguh kami telah melihat wajahmu menengadah ke langit, maka sungguh kami palingkan wajahmu ke qiblat yang kamu ridhai, maka palingkanlah wajahmu ke arah Masjid Al-Haram.' (QS. Al-Baqarah 144), lalu seorang laki-laki dari Bani Salimah berjalan, sedangkan mereka dalam keadaan rukuk dalam shalat shubuh, dan mereka telah melakukan shalat satu raka'at, lalu dia memanggil, ketahuilah, sesungguhnya qiblat telah diganti, maka mereka berpaling sebagaimana mereka menghadap qiblat. (HR. Muslim). 
h. HR. Muslim :

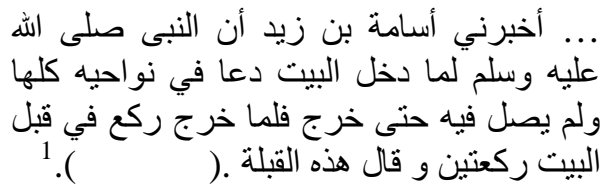

Artinya : ... Usamah bin Zaid mengkhabarkan kepadaku bahwasanya Nabi Saw. saat memasuki Baitullah ia berdo'a di sudut-sudutnya, dan tidak shalat di dalamnya sampai beliau keluar, kemudian setelah keluar beliau shalat dua raka'at di depan Ka'bah, lalu berkata; inilah qiblat (Ka'bah). (HR. Muslim).

i.HR. Abu Daud

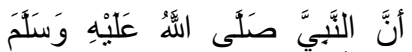

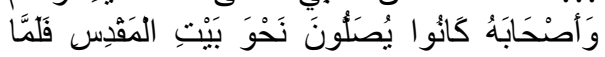

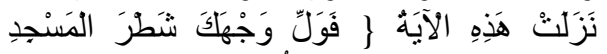

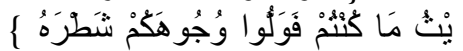

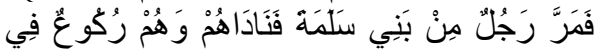

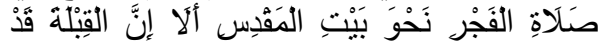

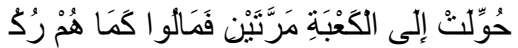

Artinya : ... dari Anas bahwa Nabi Saw. dan para sahabatnya shalat menghadap ke arah Baitul Maqdis, ketika turun ayat; Palingkanlah mukamu ke arah Masjidil Haram. dan dimana saja kamu berada, palingkanlah mukamu ke arahnya. (QS Al Baqarah; 144), lalu seorang laki-laki dari Bani Salamah lewat dan berseru kepada kaumnya ketika mereka sedang ruku' dalam shalat dengan menghadap Baitul Maqdis; Ketahuilah, bahwa qiblat telah di alihkan ke Ka'bah -ia

\footnotetext{
${ }^{1}$ Muslim bin Hajjaj al-Naisaburi, Shahih Muslim (Beirut: Dar al-Ihya alTurast, t.t.), Jilid 2, h. 968. Lihat juga: Muhammad bin Ishaq bin Khuzaimah, Shahih Ibn Khuzaimah (Beirut : alMaktabah al-Islami, 1970), Jilid 1, h. 224.
}

berseru dua kali- akhirnya mereka beralih ke Ka'bah dalam posisi $r u k u '$." (HR. Abu Daud).

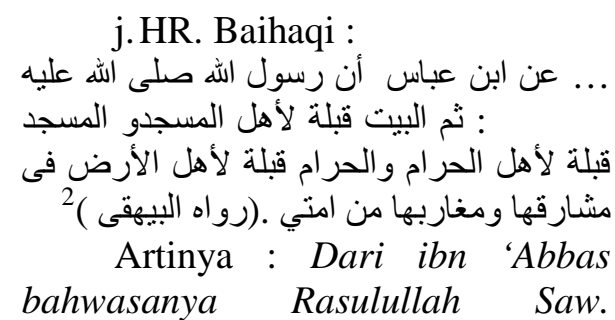

bersabda : Baitullah adalah qiblat bagi orang-orang di Masjidil Haram, Masjidil Haram adalah qiblat bagi orang-orang penduduk Tanah Haram (Mekah), dan Tanah Haram (Mekah) adalah qiblat bagi semua umatku di bumi, baik di darat ataupun di timur. (HR. Baihaqi).

\section{Dalil Ijma'}

Adapun dalil Ijma' tentang keharusan menghadap qiblat saat shalat adalah dapat ditemukan sebagaimana disebutkan dalam alFiqh 'ala al-Mazahib al-Arba'ah:

$$
\text { "Umat Islam telah sepakat }
$$
bahwa menghadap qiblat adalah merupakan syarat sah shalat".

Dengan demikian para Ulama juga telah sepakat bahwa menghadap qiblat merupakan syarat sah shalat. Hal ini juga senada dengan apa yang pernah dikutif oleh Imamul Muttaqin dalam Tesisnya bahwa Ulama-Ulama banyak yang berpendapat sama dan senada dengan ini.

${ }^{2}$ Ahmad bin Husein bin Abu Bakar al-Baihaqi, Sunan al-Baihaqi alKubra (Mekah Al-Mukarramah : Maktabah Dar al-Baz, 1944), h. 9.

3 Abdurrahman al-Jaziri, al-Fiqh 'ala al-Mazahib al-Arba'ah (Beirut : Dar alFikr, tt.), Jilid I, h. 196 


\section{Pemaknaan Kalimat Masjidil Haram}

Memaknai kalimat Masjidil Haram sebagai petunjuk dalil dalam menghadap arah qiblat adalah sebagai berikut :

Imam Nawawi dalam alMajmu' Syarah Muhazzab ${ }^{1}$ menjelaskan tentang makna kalimat Masjid al-Haram, yaitu :

المر اد بالمسجد الحر ام هنا : الكعبة نفسها

Artinya : yang dimaksud dengan Masjid al-Haram di sini adalah bangunan Ka'bah.

Namun, beliau menjelaskan bahwa pemaknaan Masjid al-Haram itu menjadi ikhtilaf (perbedaan) di kalangan ahli fiqh, masing-masing memiliki dalil dalam memperkuat ijtihadnya, yaitu :

واعلم أن المسجد الحرام قد يطلق ويردابه الكعبة

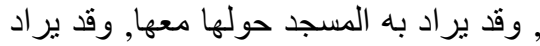
به مكة كلها , وقد بر اد به مكة مع الحرام حولهما بكماله

"Ketahuilah bahwasanya Masjid al-Haram itu kadang-kadang dipahami dan yang dimaksud dengannya adalah Ka'bah saja, terkadang yang dimaksud adalah Masjid al-Haram dan sekitarnya, terkadang yang dimaksud adalah seluruh kota Mekah, terkadang yang dimaksud adalah seluruh kota Mekah dan seluruh Masjid alHaram”.

Kalimat itu bisa dipahami bahwa, maksud Masjid al-Haram itu adalah :

1. Ka'bah (hanya Ka'bah)

1 Abu Zakaria Muhyiddin Nawawi, al-Majmu' Syarah Muhazzab (Beirut : Dar al-Kutub al-'Ilmiah, 2007), Jilid 4, h. 209.

${ }^{2}$ Ibid, h. 209.
Pendapat ini di antaranya berdasarkan dalil QS. Al-Baqarah/2; 144, :

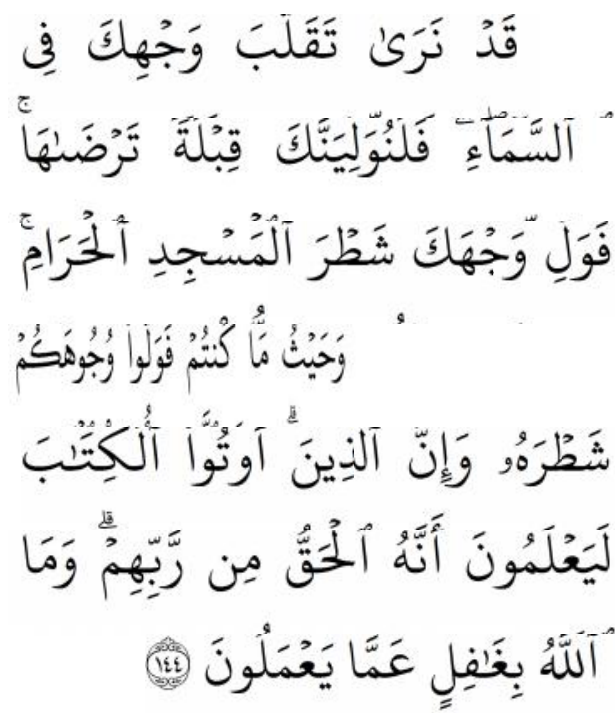

Artinya : ... palingkanlah mukamu ke arah Masjidil Haram. .... (QS. Al-Baqarah/2: 144).

Adapun pemaknaan Masjidil Haram itu berdasarkan penjelasan ayat ini di antaranya adalah 'Ainul $K a ' b a h$. Hal ini dijelaskan bahwa

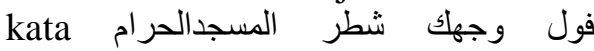
terulang sampai tiga kali, menurut Fakhruddin ar-Razi bahwa ungkapan itu karena disesuaikan dengan keadaan, ungkapan yang pertama adalah ditujukan pada orang-orang yang menyaksikan Ka'bah (Ainul Ka'bah).

2. Masjid al-Haram dan sekitarnya

Pendapat ini didasarkan pada HR. Ahmad ;

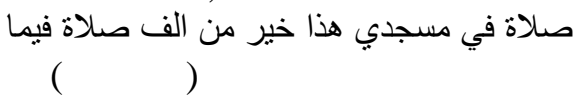

Shalat di Masjidku ini (Masjid Nabawi) lebih baik dari seribu shalat di Masjid lain, kecuali melaksanakan shalat di Masjid al-Haram. (HR. Ahmad). 


$$
\text { ومسجدي هذا و المسجد الأقصى : }
$$

Artinya : Tidak dibolehkan melakukan perjalanan kecuali menuju tiga Masjid, yaitu ; Masjidil Haram, Masjid-Ku ini (Masjid Nabawi) dan Masjid al-Aqsha. (HR. Bukhari).

Adapun pemaknaan Masjidil Haram itu berdasarkan penjelasan dalil-dalil ini di antaranya juga adalah tetap dengan makna Masjidil Haram itu.

3. Seluruh kota Mekah

Pendapat ini didasarkan pada QS. al-Isra'/17 ;1:

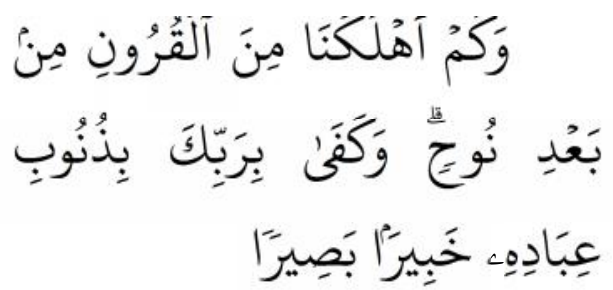

Artinya : Maha suci Allah, yang telah memperjalankan hambaNya pada suatu malam dari AlMasjidil Haram ke Al-Masjidil Aqsha...(QS. Al-Isra'/17; 1).

Mekah didefenisikan sebagai Masjidil Haram berdasarkan ayat di atas karena awal mula peristiwa isra' dan $m i$ 'raj, dimulai dari kota Mekah.

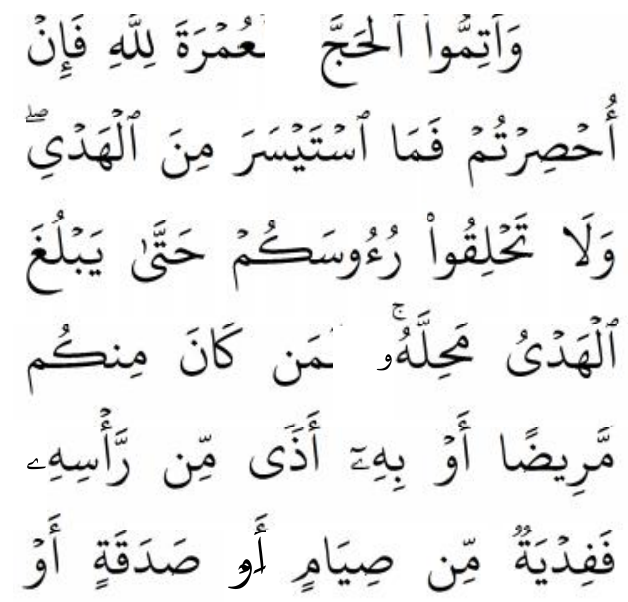

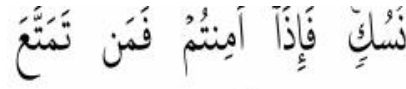

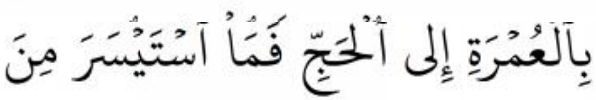

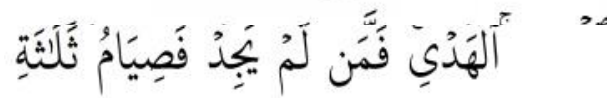

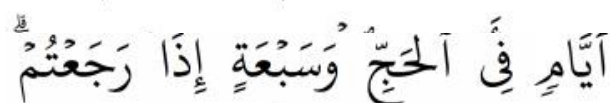

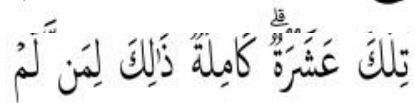

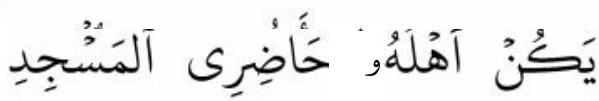

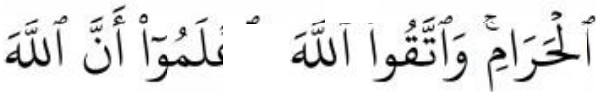
شَدِيُ ألَعِقَابِ

Artinya : ... tetapi jika ia tidak menemukan (binatang korban atau tidak mampu), maka wajib berpuasa tiga hari dalam masa haji dan tujuh hari (lagi) apabila kamu telah pulang kembali. Itulah sepuluh (hari) yang sempurna, demikian itu (kewajiban membayar fidyah) bagi orang-orang yang keluarganya tidak berada (di sekitar) Masjidil Haram (orang-orang yang bukan penduduk kota Mekah), ... (QS. Al-Baqarah/2; 196).

Adapun yang dimaksud dengan Masjidil Haram dalam ayat ini adalah kota Mekah, sehingga bisa dipahami bahwa pemaknaan Masjidil Haram itu di antaranya adalah Mekah.

4. Seluruh kota Mekah dan seluruh Masjid al-Haram

Pendapat ini juga didasarkan pada QS. al-Taubah/9; 28:

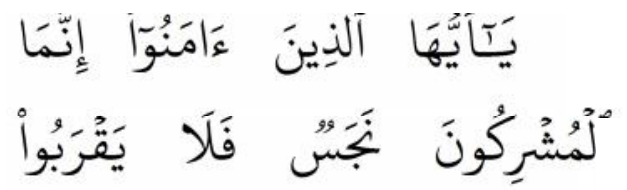




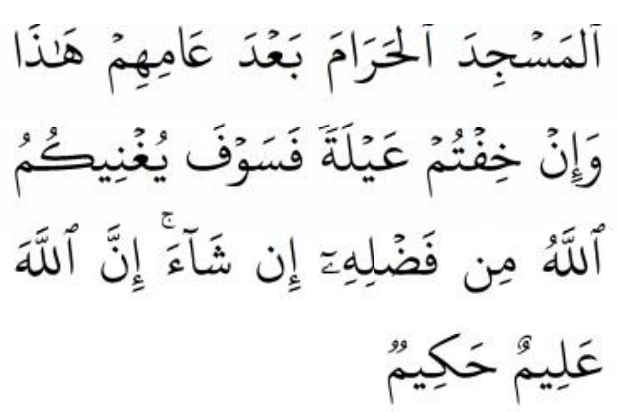

Artinya : Hai orang-orang yang beriman, sesungguhnya orangorang yang musyrik itu najis, maka janganlah mereka mendekati Masjid al-Haram sesudah tahun ini...(QS. al-Taubah/9; 28)

Adapun yang dimaksud dengan Masjidil Haram dalam ayat ini adalah larangan bagi orang-orang musyrik untuk memasuki kota Mekah dan Masjidil Haram seluruhnya, sehingga bisa dipahami bahwa pemaknaan Masjidil Haram itu di antaranya juga adalah Mekah dan Masjidil Haram seluruhnya.

Pemaknaan Masjidil Haram itu menjadi beragam, ada 'ainul Ka'bah, Masjidil Haram dan Mekah, namun Imam Nawawi memperjelas bahwa "yang dimaksud dengan Masjid alHaram di sini adalah bangunan $K a$ 'bah", hal ini juga diperkuat oleh Muhammad Ali Ash-Shabuni dalam Tafsir Ahkamnya :

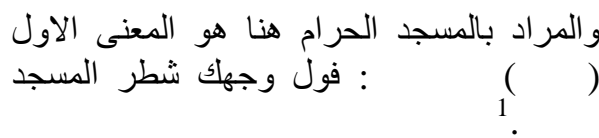
Artinya : Adapun yang dimaksud dengan Masjidil Haram di sini adalah pendapat yang pertama (yaitu Ka'bah), maka makna ayatnya

\footnotetext{
${ }^{1}$ Muhammad Ali Ash-Shabuni, Rawai'ul Bayan Tafsir Ayat al-Ahkam min Al-Qur'an (Beirut : Dar al-Kutub Islamiyah, 2001), Jilid I, h. 95.
}

adalah: maka palingkanlah wajahmu ke arah Ka'bah.

Berdasarkan dalil tersebut maka dipahami bahwa menghadap ke arah qiblat menjadi suatu keharusan dan kewajiban bagi umat Islam yang hendak menunaikan shalat baik shalat fardhu lima waktu sehari semalam atau shalat-shalat sunat yang lain. Terlepas apakah qiblat yang dimaksud dengan kalimat Masjdi al-Haram itu diartikan Ka'bah saja, Masjid al-Haram dan sekitarnya, seluruh kota Mekah atau seluruh kota Mekah dan seluruh Masjid al-Haram.

\section{Meretas Kebekuan Ijtihad Arah Qiblat}

Menghadap qiblat berkaitan dengan ritual ibadah yakni shalat, ia baru merupakan keharusan untuk dilakukan setelah ada ketetapan atau dalil yang menunjukkan bahwa menghadap qiblat itu wajib.

Dalam kaidah fiqhiyah dijelaskan : العبادة البطلان حتى يقوم الدليل على

2

Artinya : Hukum pokok dalam lapangan ibadah itu adalah bathal sampai ada dalil yang memerintahkan.

Hal ini berarti bahwa lapangan ibadah, pada hakekatnya segala perbuatan harus menunggu adanya perintah. Ada beberapa Nash yang memerintahkan kita untuk menghadap qiblat dalam shalat baik Al-Qur' an maupun Hadis.

Jika diperhatikan tentang pelaksanaan ibadah shalat misalnya, ia baru dikatakan sah jika

2 Asjmuni A. Rahman, QaidahQaidah Fiqih (Qawa'idul Fiqhiyyah) (Jakarta : Bulan Bintang, 1976), cet. Ke-1, h. 43. 
melaksanakan shalat itu sudah masuk waktu, contohnya shalat zuhur, shalat zuhur baru dikatakan sah dilaksanakan jika shalat zuhur itu dilaksanakan setelah masuk waktu shalat zuhur, seandainya shalat zuhur tersebut dilaksanakan sebelum waktunya masuk dan hal itu diketahui dengan pasti tidak atau belum masuk waktu shalat zuhur, maka ulama sepakat bahwa hal itu tidak sah. Berbeda halnya jika tidak tahu, atau dahulu menentukan waktu seperti ini....atau seperti itu.... misalnya, dikemudian hari, ditemukan cara atau metode baru dalam menentukan waktu shalat yang lebih akurat dan pasti, maka kita wajib untuk mengikuti yang lebih baik, akurat dan pasti, sebab kalau kita berdiam diri padahal kita tahu itu sudah tidak akurat dan tidak benar, maka saya pikir (jika seandainya boleh dikatakan ijtihad) hal ini juga bisa mengakibatkan shalat seseorang itu tidak sah.

Ilustarasi ini jika seandainya bisa disamakan dengan qiyas dalam pendekatan ushul fiqh, maka menurut saya persoalan menghadap qiblatpun bisa diqiyaskan dengan pelaksanaan ibadah shalat, jika melaksanakan shalat tidak benar waktunya, maka shalatnya tidak sah (dan ia tahu tidak benar masuk waktu shalat), demikian juga menghadap qiblat, jika dia tahu bahwa menghadap qiblat tersebut tidak benar, maka ibadah shalatnya pun tidak sah. Menurut penulis dalam hal ini, bahwa pemaknaan arah qiblat itu hanya ada tiga; 'Ainul Ka'bah, Masjidil Haram dan Tanah Haram;Mekah, selain itu maka arah qiblat menurut penulis sudah keluar dari makna arah qiblat di atas, sebab tidak ada dalil yang mendukungnya secara pasti dan muktamad (bisa diperpegangi). Ala kulli hal, hemat penulis, kesamaan pemaknaan arah dan waktu merupakan lambang batasan yang harus pasti dan dipastikan, arah adalah lambang batasan tepat (harus tepat mengarah qiblat), sedangkan waktu adalah lambang batasan tempo atau masa (harus tepat masuk waktu).

Jika seandainya ada yang menganggap atau mengira bahwa menentukan arah qiblat itu suatu hal yang sulit, sedangkan Allah mengatakan bahwa tidak akan mempersulit dalam hal agama, sebagaimana dalam firmannya:

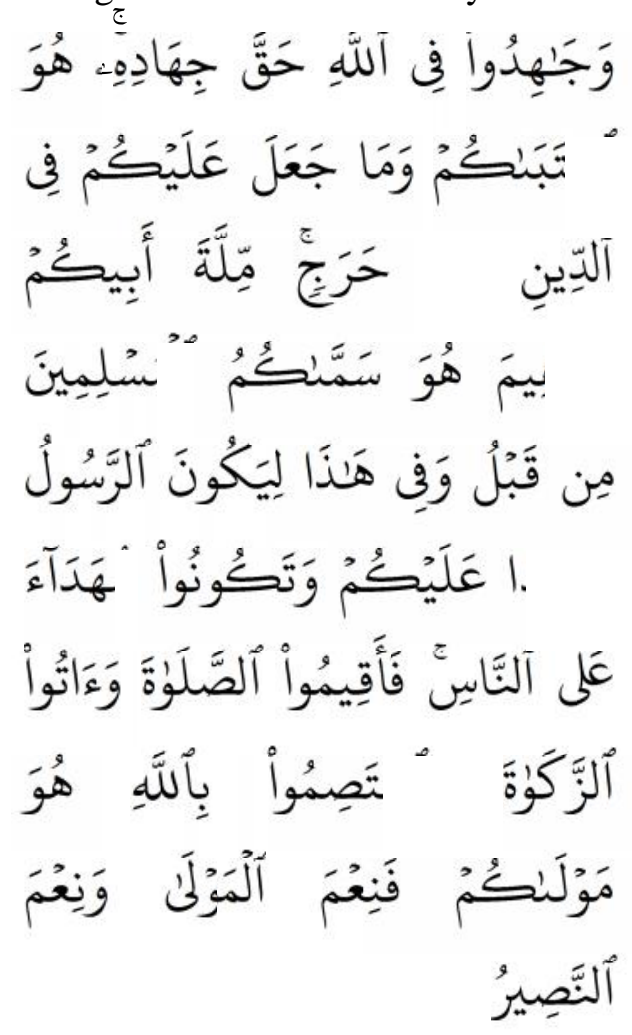

Artinya : ....dan Dia sekali-kali tidak menjadikan untuk kamu dalam agama suatu kesempitan...(QS.AlHajj/22; 78). 
Menentukan arah qiblat itu, untuk saat ini tidak lagi hal yang sulit, dengan segala macam metode yang ada dalam ilmu astronomi atau ilmu falak dan didukung oleh peralatan yang sangat beragam dan saling mendukung tentang ketepatan akurasi arah qiblatnya, suatu hal yang mustahil dikatakan sulit, menentukan arah qiblat secara tepat (dalam makna yang tiga: 'Ainul Ka'bah, Masjidil Haram dan Tanah Haram; Mekah ) adalah merupakan ijtihad arah qiblat yang mesti dan niscaya harus dilakukan saat sekarang ini.

Jika ada pertanyaan tentang bagaimana status hukum shalat yang telah dilaksanakan oleh muslim dahulu, yang saat ini ternyata tempat shalat mereka (Masjid/Mushalla) dinyatakan mengalami deviasi/penyimpangan ?, maka menurut Hemat Penulis, bahwa persoalan menentukan arah qiblat adalah persoalan ijtihadi, yang terus mengalami perkembangan oleh karena faktor-faktor sains yang mendukung, kalau dahulu menentukan arah qiblat itu kemungkinan rata-rata umat mendasarkan pada matahari tenggelam untuk kawasan Indonesia, saat itu, hanya itulah metode yang diketahui dan sampai disitulah kemampuan ilmu dan pengetahuan umat tentang menentukan arah qiblat, jadi ibadah shalatnya tetap sah. Sekalipun saat ini sudah ditemukan metode atau ilmu pengetahuan yang lebih pasti tentang penentuan arah qiblat (didukung oleh sains) hukum shalat yang dilakukan oleh umat terdahulu tetap sah, karena hukum itu tidak saling membatalkan dalam masalah ijtihadiyah, dalam hal ini muncullah kaidah yang populer :

1. الحكم لا ينقض با لاجتهاد

Artinya : Hukum itu tidak batal dengan ijtihad.

Ada juga istilah menyebutkan,

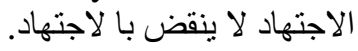

Artinya : Ijtihad itu tidak batal dengan ijtihad.

Seandainya menghadap arah qiblat yang dilakukan di luar pemaknaan yang tiga: 'Ainul Ka'bah, Masjidil Haram dan Tanah Haram; Mekah, dan itupun bagian dari ijtihad, maka apakah shalat dengan pemahaman qiblat seperti itu juga sah ? hemat saya, kalau hal itu dianggap merupakan ijtihad maka shalat tetap sah. Cuma pertanyaan berikutnya adalah, apakah hasil dari ijtihad seperti ini sudah maksimal ? menurut saya, untuk saat sekarang ini, dengan didukung oleh perkembangan sign/ilmu pengetahuan dan peralatan yang modern serta canggih dan bisa dibuktikan bahwa pemaknaan arah qiblat seperti "arah yang sebelumnya" salah, maka ijtihad itu harus dirubah, ijtihad itu bukan sesuatu yang qath'i, atau absolute sehingga tidak boleh dirubah pemaknaannya, ijtihad itu harus berkembang.

Kaidah Ushul Fiqh berikutnya : الامر بالثيء امر بوسائله .

Artinya: memerintahkan sesuatu berarti memerintahkan apa yang menjadi penghubung/perantaranya. Dengan demikian ketika Allah memerintahkan shalat, berarti segala hal yang berkaitan dengan shalat harus dilaksanakan, termasuk di

1 Lihat: Amir Syarifuddin, Ushul Fiqh 2 (Jakarta: Kencana Prenadamedia Group, 2014), h. 343. 
antaranya adalah perintah menghadap arah qiblat ketika shalat, melaksanakan shalat itu harus benar dalam pelaksanaannya, jika tidak pasti belum shalatnya namanya (bahasa hukum; tidak sah), demikian juga menghadap qiblat harus benar cara menghadapnya, jika tidak pasti belum menghadap qiblat namanya (bahasa hukum; tidak sah).

Kaidah Ushul Fiqh berikutnya : مالا يتم الوجب الابه فهو واجب .

Artinya : sesuatu yang tidak sempurna wajib kecuali dengannya, maka hal itu menjadi wajib.

Dengan kaidah ini bisa dipahami bahwa mengetahui arah qiblat yang benar akan menjadi wajib, karena melaksanakan ibadah shalat fardhu 5 waktu itu adalah wajib. Adapun menjadi ahli (expert) dalam mengukur arah qiblat atau ahli falak adalah bagian fardhu kipayah yang harus ada di antara kaum muslimin.

Kemudian, menghadap ke arah qiblat dalam pelaksanaannya membutuhkan sesuatu yang pasti dan harus bisa dipastikan, sehingga menjadi qiblatul yaqin (yakin menghadap qiblat). Pemahaman tersebut bisa disederhanakan dengan konsep ijtihad dalam menentukan arah qiblat, yaitu :

1. Menghadap qiblat yakin (qiblatul yaqin)

Seseorang yang berada di dalam Masjidil Haram dan melihat langsung Ka'bah, wajib menghadapkan dirinya ke qiblat dengan penuh yakin. Ini yang juga disebut sebagai "Ainul Ka'bah". Kewajiban tersebut bisa dipastikan terlebih dahulu dengan melihat atau menyentuhnya (bagi orang yang buta) atau dengan cara lain yang bisa digunakan misalnya pendengaran, termasuk ilmu pengetahuan. Sedangkan bagi seseorang yang berada dalam bangunan Ka'bah itu sendiri maka qiblatnya adalah dinding Ka'bah.

2. Menghadap qiblat perkiraan (qiblatul dzan).

Seseorang yang berada jauh dari Ka'bah yaitu berada diluar Masjidil Haram atau di sekitar tanah suci Mekah sehingga tidak dapat melihat bangunan Ka'bah, mereka wajib menghadap ke arah Masjidil Haram sebagai maksud menghadap ke arah qiblat secara $d z a n$ atau kiraan atau disebut sebagai "Jihatul Ka'bah". Untuk mengetahuinya dapat dilakukan dengan bertanya kepada mereka yang mengetahui seperti penduduk Mekah atau melihat tanda-tanda qiblat atau "shaff" yang sudah dibuat di tempattempat tersebut, termasuk dengan ilmu pengetahuan.

3. Menghadap qiblat ijtihad (qiblatul ijtihad).

Seseorang yang berada di luar tanah suci Makkah atau bahkan di luar negara Arab Saudi, sehingga sulit atau tidak dapat melihat bangunan Ka'bah, bagi mereka wajib menghadap ke arah Masjidil Haram (dalam makna Mekah) sebagai maksud menghadap ke arah qiblat secara ijtihad (qiblatul ijtihad).

Bagi yang tidak tahu arah dan ia tidak dapat mengira qiblat dzannya maka ia boleh menghadap kemanapun yang ia yakini sebagai arah qiblat. Namun bagi yang dapat mengira maka ia wajib ijtihad terhadap arah qiblatnya. Ijtihad dapat digunakan untuk menentukan arah qiblat dari suatu tempat yang terletak jauh dari Masjidil Haram. Di 
antaranya adalah ijtihad menggunakan posisi rasi bintang, bayangan matahari, dan perhitungan segitiga bola maupun pengukuran menggunakan peralatan modern.

\section{Kesimpulan}

Dari beberapa pendapat di atas, dapat disimpulkan bahwa tentang kewajiban menghadap Ka'bah adalah bagi orang yang mampu melihat Ka'bah secara langsung. Akan tetapi bagi orang yang jauh dari Mekah dan tidak dapat melihat Ka'bah secara langsung, mayoritas para Ulama hanya mewajibkan menghadap ke arah Ka'bah (jihatul Ka'bah). Dengan kata lain, qiblat bagi orang yang melihat langsung Ka'bah adalah 'ainul $\mathrm{Ka}$ 'bah, sedangkan qiblat bagi orang yang tidak dapat melihat langsung Ka'bah adalah jihatul Ka'bah. Namun bila dikaji ulang, sebenarnya para Ulama memiliki komitmen bahwa bagi orang yang dapat melihat Ka'bah, dan orang yang tidak dapat melihat Ka'bah tapi sebenarnya ia dapat berijtihad untuk mengetahui arah menuju Ka'bah (jihatul Ka'bah), maka mereka wajib menghadap ke bangunan Ka'bah ('ainul Ka'bah).

Dari istilah 'ainul Ka'bah dan jihatul Ka'bah, sebenarnya yang dituju satu titik yaitu Ka'bah di Mekah. 'Ainul Ka'bah adalah bangunan Ka'bah itu sendiri, sedangkan jihatul Ka'bah adalah arah menuju Ka'bah. Oleh sebab itu, untuk mengarah ke Ka'bah, tidak boleh asal menghadap, dalam artian diperlukan suatu perhitungan untuk mengarah ke Ka'bah. Apalagi dengan adanya keilmuan dan teknologi yang ada sekarang, perhitungan untuk mengarah ke titik
Ka'bah menjadi lebih mudah dengan akurasi yang dapat dipertanggungjawabkan. Bila demikian, keilmuan dan teknologi tentu dapat ikut serta berperan dalam menyempurnakan ibadah ibadah umat Islam yaitu menghadap qiblat lebih tepat untuk keabsahan ibadah shalat. ${ }^{1}$

Namun demikian untuk orang yang tidak dapat melihat Ka'bah maka bagi mereka ada toleransi untuk menghadap ke Masjidil Haram bagi orang yang ada di Mekah, sedangkan bagi orang yang ada di luar Mekah bagi mereka juga ada toleransi untuk menghadap ke Mekah.[]

\section{Daftar Pustaka}

A. Rahman, Asjmuni. QaidahQaidah Fiqih (Qawa'idul Fiqhiyyah ). Jakarta : Bulan Bintang, 1976, cet. Ke-1.

Al-Ashbahani, Abu Na'im Ahmad bin Ishaq. Al-Musnad AlMustakhraj 'Ala Shahih Imam Muslim. Beirut : Dar al-Kutub, 1996, Jilid 2.

Al-Baihaqi, Ahmad bin Husein bin Abu Bakar. Sunan al-Baihaqi al-Kubra. Mekah AlMukarramah : Maktabah Dar al-Baz, 1944.

Al-Bukhory, Abi Abdillah Muhammad bin Ismail bin Ibrahim ibn al-Mughiroh bin Bardazbah. Shahih al-

1 Penjelasan ini telah dikutif dari : Kementerian Agama RI. Kajian Terhadap Metode-Metode Penentuan Arah Kiblat dan Akurasinya (Jakarta: Kemenag RI, 2012), h. 46-47. 
Bukhari. Kairo : Dar alHadis, 2004, Jilid 1.

Al-Ghalayaini, Musthofa. Jami'ud Durusul 'Arabiyyah. Beirut: Mansyuratul Maktabul 'Ishriyyah, t.th.

Al-Jaziri, Abdurrahman. al-Fiqh 'ala al-Mazahib al-Arba'ah. Beirut : Dar al-Fikr, tt., Jilid I.

Al-Maraghi, Ahmad Mustafa. Terjemah Tafsir Al-Maraghi, penerjemah : Anshori Umar Sitanggal. Semarang: CV. Toha Putra, 1993, Juz II.

Al-Naisaburi, Imam Abi Husain Muslim bin Hujja ibn Muslim al-Qusyairi. al-Jami'us Shahih. Beirut : Dar al-Fikri, tth, Juz I.

Al-Naisaburi, Muslim bin Hajjaj. Shahih Muslim. Beirut: Dar al-Ihya al-Turast, t.t., Jilid 2.

Al-Tirmidzi, Muhammad bin Isa. Sunan Tirmidzi. Beirut : Dar al-Ihya al-Turast, t.t., Jilid 2.

Ash-Shabuni, Muhammad Ali. Rawai'ul Bayan Tafsir Ayat al-Ahkam min Al-Qur'an. Beirut : Dar al-Kutub Islamiyah, 2001, Jilid I.

Brink, Jan van den dan Marja Meeder. Kiblat Arah Tepat Menuju Mekah, disadur oleh Andi Hakim Nasution dari "Mecca". Jakarta : Litera Antar Nusa, 1993, cet. 1.

Dahlan, Abdul Aziz. et al., Ensiklopedi Hukum Islam. Jakarta: PT. Ichtiar Baru Van Hoeve, 1996, Cet. Ke-1.

Depag. Pedoman Penentuan Arah Kiblat. Jakarta: Dirjen Binbaga Islam Dirbinpera, 1996.
Departemen Agama RI., Direktorat Jenderal Pembinaan Kelembagaan Agama Islam Proyek Peningkatan Prasarana dan Sarana Perguruan Tinggi Agama/IAIN. Ensiklopedi Islam. Jakarta: CV. Anda Utama, 1993.

Departemen P \& K,. Kamus Besar Bahasa Indonesia. Jakarta : Balai Pustaka, 1989), cet. 2.

Departemen Pendidikan Nasional. Kamus Besar Bahasa Indonesia. Jakarta: Balai Pustaka, 2007. Edisi Ketiga.

Effendy, Mochtar. Ensiklopedi Agama dan Filsafat. Palembang: Universitas Sriwijaya, 2001, Cet. Ke-1, Vol. 5.

Hambali, Slamet. Ilmu Falak I : Penentuan Awal Waktu Shalat dan Arah Kiblat Seluruh Dunia. Semarang: Program Pascasarjana IAIN Walisongo Semarang, 2011.

Izzuddin, Ahmad. Ilmu Falak Praktis: Metode HisabRukyat Praktis dan Solusi Permasalahannya. Semarang: PT. Pustaka Rizki Putra, 2012.

Kementerian Agama RI. Kajian Terhadap Metode-Metode Penentuan Arah Kiblat dan Akurasinya. Jakarta: Kemenag RI, 2012.

Khazin, Muhyiddin. Ilmu Falak Dalam Teori dan Praktik. Yogyakarta: Buana Pustaka, 2004.

Khuzaimah, Muhammad bin Ishaq bin. Shahih Ibn Khuzaimah. Beirut : al-Maktabah alIslami, 1970, Jilid 1. 
Ma'luf, Louwis. Al-Munjid. Mesir: Dar al-Masyriq, 1975. Cet ke-25.

Munawwir, Ahmad Warson. Kamus al-Munawwir Arab Indonesia Terlengkap. Yogyakarta : Pustaka Progresif, 1984. cet. I.

Nasution, Harun. et.al., Ensiklopedi Hukum Islam. Jakarta: Djambatan, 1992.

Nawawi, Abu Zakaria Muhyiddin.alMajmu' Syarah Muhazzab.
Beirut : Dar al-Kutub al'Ilmiah, 2007, Jilid 4.

Nur, Nurmal. Ilmu Falak (Teknologi Hisab Rukyat Untuk Menentukan Arah Kiblat, Awal Waktu Shalat dan Awal Bulan Qamariah). Padang: IAIN Imam Bonjol Padang, 1997.

Syarifuddin, Amir. Ushul Fiqh 2. Jakarta: Kencana Prenadamedia Group, 2014. 
